\title{
ATRIBUIÇÃO DO TÍTULO DE DOUTOR HONORIS CAUSA PELA UNIVERSIDADE DE LISBOA
}

\author{
DOI: http://dx.doi.org/10.1590/2236-3459/58402
}

Maria Stephanou

\section{A Universidade de Lisboa atribui o título de Doutor Honoris Causa a $\triangle$ personalidades eminentes, nacionais ou estrangeiras, que tenham se distinguido na atividade acadêmica, científica, profissional, cultural, artística, cívica ou política, ou que hajam prestado altos serviços à Universidade, ao país ou à} humanidade.

A proposta para a atribuição do título de Doutor Honoris Causa inicia com a apresentação ao reitor da Universidade do curriculum vitae da personalidade a distinguir, apresentado pelo diretor ou presidente de uma faculdade ou instituto, após aprovação por maioria de dois terços dos membros de seu conselho científico.

A atribuição do título de Doutor Honoris Causa a individualidades estrangeiras é decidida pelo reitor, precedida de audição do Ministro dos Negócios Estrangeiros e, posteriormente, é realizada em cerimônia pública.

No dia 23 de abril de 2015, por proposta do Instituto de Educação, receberam este título Sérgio Niza e Agustín Escolano. Com esta distinção, reservada a personalidades eminentes que se notabilizaram pelo seu curriculum de reconhecimento internacional, a Univesidade de Lisboa homenageou e reconheceu o contributo de figura marcante e inspiradora da Educação e, em particular, da Pedagogia e da História da Educação.

A cerimónia contou com a participação do professor doutor António Sampaio da Nóvoa e do professor doutor Justino Pereira de Magalhães, que fizeram o elogio dos doutorandos na qualidade de padrinhos.

O curriculum vitae do prof. dr. Agustín Escolano assim foi apresentado por ocasião do convite à homenagem:

"É um reconhecido académico, humanista e homem de ciência, cuja obra científica e magistral é inseparável da renovação da História da Educação espanhola, europeia e ibero-americana, bem assim como da valorização da Educação e das Ciências da Educação na Universidade, nas Humanidades e no desenvolvimento da sociedade contemporânea. Catedrático da Universidad de Valladolid, Agustín Escolano Benito fundou e dirigiu as revistas Studia Paedagogica e Historia de la Educación; é autor de 21 livros e de 271 artigos, editor e coautor de 17 obras que contaram com a colaboração dos mais prestigiados investigadores; orientou 36 teses doutorais; coordenou e ficou associado a 42 projetos científicos e culturais com âmbito internacional. Os seus trabalhos estão traduzidos em diferentes línguas. Fundou e é diretor do Centro Internacional de Cultura Escolar, com apoio da Fundación Germán Sánchez Ruipérez e 
da Consejeria de Educación de la Junta de Castilla. Tem colaborado regularmente com a Universidade de Lisboa." [http://www.ie.ulisboa.pt/portal/page?_pageid=406,1864965\&_ dad=portal\&_schema=PORTAL]

A revista História da Educação se sente honrada com a autorização do professor Escolano para a publicação inédita no Brasil, do discurso e do elogio desta homenagem.

Os editores.
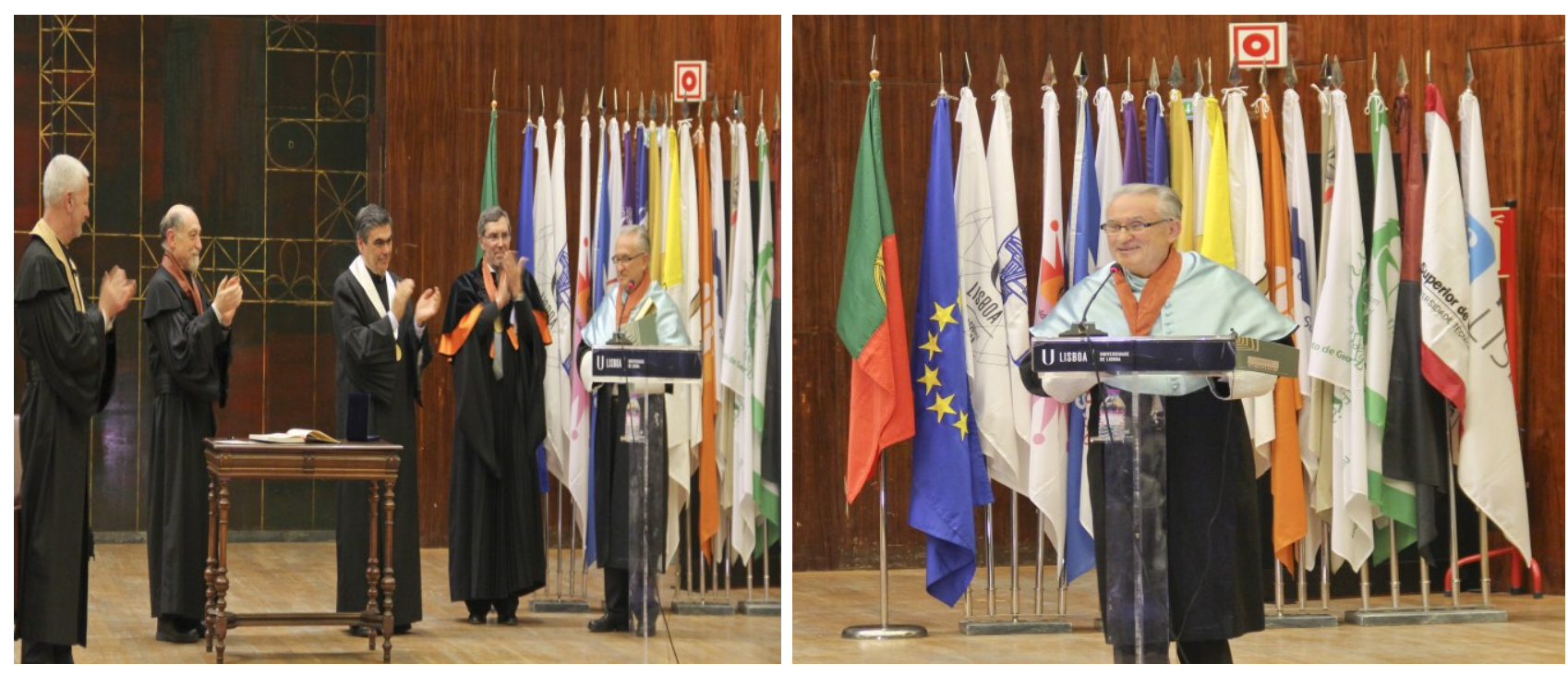